\title{
CONFIRMED CASES OF MALARIA IN BRAZIL BETWEEN 2011 AND 2015
}

\section{ORIGINAL ARTICLE}

ALMEIDA, Hellen Karine Santos ${ }^{1}$

FECURY, Amanda Alves ${ }^{2}$

OLIVEIRA, Euzébio ${ }^{3}$

DENDASCK, Carla Viana ${ }^{4}$

DIAS, Claudio Alberto Gellis de Mattos ${ }^{5}$

ALMEIDA, Hellen Karine Santos. Et al. Confirmed cases of malaria in Brazil between 2011 and 2015. Revista Científica Multidisciplinar Núcleo do Conhecimento. Year 05, Ed. 04, Vol. 07, pp. 05-16. April 2020. ISSN:2448-0959, Access link in: https://www.nucleodoconhecimento.com.br/health/malaria-in-brazil, DOI: 10.32749/nucleodoconhecimento.com.br/health/malaria-in-brazil

\footnotetext{
${ }^{1}$ Mining technician by the Institute of Basic, Technical and Technological Education of Amapá (IFAP).

2 Biomedical, PhD in Topical Diseases, Professor and researcher of the Medicine Course at Campus Macapá, Federal University of Amapá (UNIFAP).

${ }^{3}$ Biologist, PhD in Topical Diseases, Professor and researcher of the Physical Education Course at, Federal University of Pará (UFPA).

4 Theologian, PhD in Psychoanalysis, researcher at the Center for Research and Advanced Studies - CEPA.

${ }^{5}$ Biologist, $\mathrm{PhD}$ in Theory and Research of Behavior, Professor and researcher of the Chemistry Degree Course at the Basic, Technical and Technological Institute of Amapá (IFAP).
} 


\section{ABSTRACT}

Malaria is a worldwide disease that causes a high number of deaths. It is caused by the bite of the Anopholes mosquito infected by the parasitic protozoan of the genus Plasmodium. The purpose of this article is to show the numbers of confirmed cases of malaria in Brazil, regarding the years of confirmation, the age group and the notification region, between the years 2011 to 2015. Data taken from the SUS IT department, DATASUS and from articles. There was a decline in the number of the period cited, people between the age group of 20 to 39 years, followed by the group between 49 and 59 years, the largest number of cases occurred with male people, the largest number of cases occurred with people of white race followed by browns, the highest number of cases per schooling is unknown where schooling is known, the highest numbers are with people from complete high school, followed by people with complete higher education, most cases occurred in an urban area , the southeastern region has the highest number of confirmed cases of malaria in the period, the highest number of cases occurred in the state of Rondônia. It is concluded that campaigns had an influence on society and collaborated with the reduction of the number of communicable diseases like malaria. Men work in areas with a higher risk of contamination and in places of vector proliferation, so they are more exposed to areas of mosquito proliferation and contagion. In Brazil the majority of the population is recognized as being white and brown, respectively, so the numbers show these ethnicities as the most infected. The mosquito seems to proliferate more easily in places where there have been man-made changes. The urban environment, as it is an extremely modified place, causes a greater number of cases due to the greater availability of breeding sites. It is believed that for this reason the southeastern region has a greater number of cases and because it is also one of the regions of the country that has suffered the most changes by man. The opening of highways and the increase in settlements facilitate contact between mosquitoes and humans. The state of Rondônia has a large number of settlements and deforestation to accommodate progress.

Keywords: Malaria, epidemiology, confirmed cases. 


\section{INTRODUCTION}

Malaria is a worldwide disease that causes a high number of deaths (Aregawi et al., 2017; Jotta and Carneiro, 2009; Camargo, 1995).

It is caused by the bite of the Anopholes mosquito infected by the parasitic protozoan of the genus Plasmodium. It can be acquired by two means: the environment modified by man and the natural environment. The most conducive to transmission is the urban environment. The action of man in transforming the environment seems to cause the mosquito that causes malaria to proliferate and transmit the disease (Barata, et al., 1993; Castro and Singer., 2007).

Malaria has several easily recognizable symptoms. The main one and characteristic of the disease is high fever. There is also an enlarged spleen, accompanied by headaches, nausea, chills and malaise (Camargo, 1995; Aregawi et al ,. 2017).

Before starting treatment, it is necessary to have knowledge about the patient's age, the Plasmodium species, the severity of the disease and the conditions the patient is in (pregnancy or other health problems). The treatment begins with the interruption of the parasite's reproduction in the body, using drugs that prevent the development of the disease. The Ministry of Health makes antimalarial drugs available for free throughout the country. The most accepted treatment today, although it has new techniques, is the "gout test", a simple, low-cost and effective test (Brasil, 2010; Brasil, 2017).

For the prevention of malaria it is essential to avoid places that have breeding grounds for malaria, such as rivers and wetlands. The use of repellents on the body and screens on doors and windows is important for people living close to the areas most at risk of disease contamination. (Brazil, 2015; Bentes, et al., 2017).

Malaria is present in about 104 countries around the planet. There are an estimated 219 million cases in 17 countries. Most are on the African continent, in which Nigeria and the Democratic Republic of Congo stand out. South America and Central America 
come next with $71 \%$ of the number of cases. South and Southeast Asia has the lowest number of registered cases, $50 \%$ in total. In Europe and North America the number of cases is unknown or null (Camargo, 2003; Santos, 2016).

Brazil, although it has obtained a decrease in the number of infected individuals, still concentrates a very high number of confirmed cases of malaria, around 200 thousand per year, since 2011. The North region of the country presented 930,486 cases of malaria between 2011 and 2015 (Santos, 2016; Grillo, et al., 2017).

In Amapá the number of cases was around 13,817, divided into settlements (655 cases), garimpos (1,724 cases), indigenous areas (1490 cases), urban areas (2,410 cases) and rural areas (7,538 cases) (Brazil, 2015).

\section{AIM}

Analyze the numbers of confirmed cases of malaria in Brazil, regarding the years of confirmation, the age group and the region of notification, between the years 2011 to 2015.

\section{METHOD}

Data taken from the SUS IT department, DATASUS (http://datasus.saude.gov.br) following the following steps: first, the "access to information" tab was selected, followed by the "health information (TABNET") option "Soon afterwards clicked on" epidemiological and morbidity ". On the next page, the option "Diseases and Notifiable Diseases - From 2007 onwards (SINAM)" was accessed. On the new page, the "Malaria" icon was selected. In the "geographical scope" tab, the option "Brazil by Region, State and Municipality" was selected. For data collection, the steps were followed: the options "Year 1 ' symptoms", "age group", "sex", and "Region of residence", "zone of residence", "education" were selected in the line field. "," Race "and" states of the northern region of Brazil ". For all of the above options, the "not active" option was selected in the column field; in the content field the option "confirmed cases"; and in available periods from 2011 to 2015 . The data was compiled using the 
Excel application, part of the Microsoft Corporation Office suite. The bibliographic search was' carried out on scientific articles, using computers from the computer lab of the Federal Institute of Education, Science and Technology of Amapá, Campus Macapá, located at: Rodovia BR 210 KM 3, s / n - Bairro Brasil New. CEP: 68.909398, Macapá, Amapá, Brazil.

\section{RESULTS}

Figure 1 shows the percentage of confirmed cases of malaria in Brazil between the years 2011 to 2015 . The data show that there was a decline in the number of the period cited.

Figure 1 Shows the percentage of confirmed cases of malaria in Brazil between the years 2011 to 2015 .

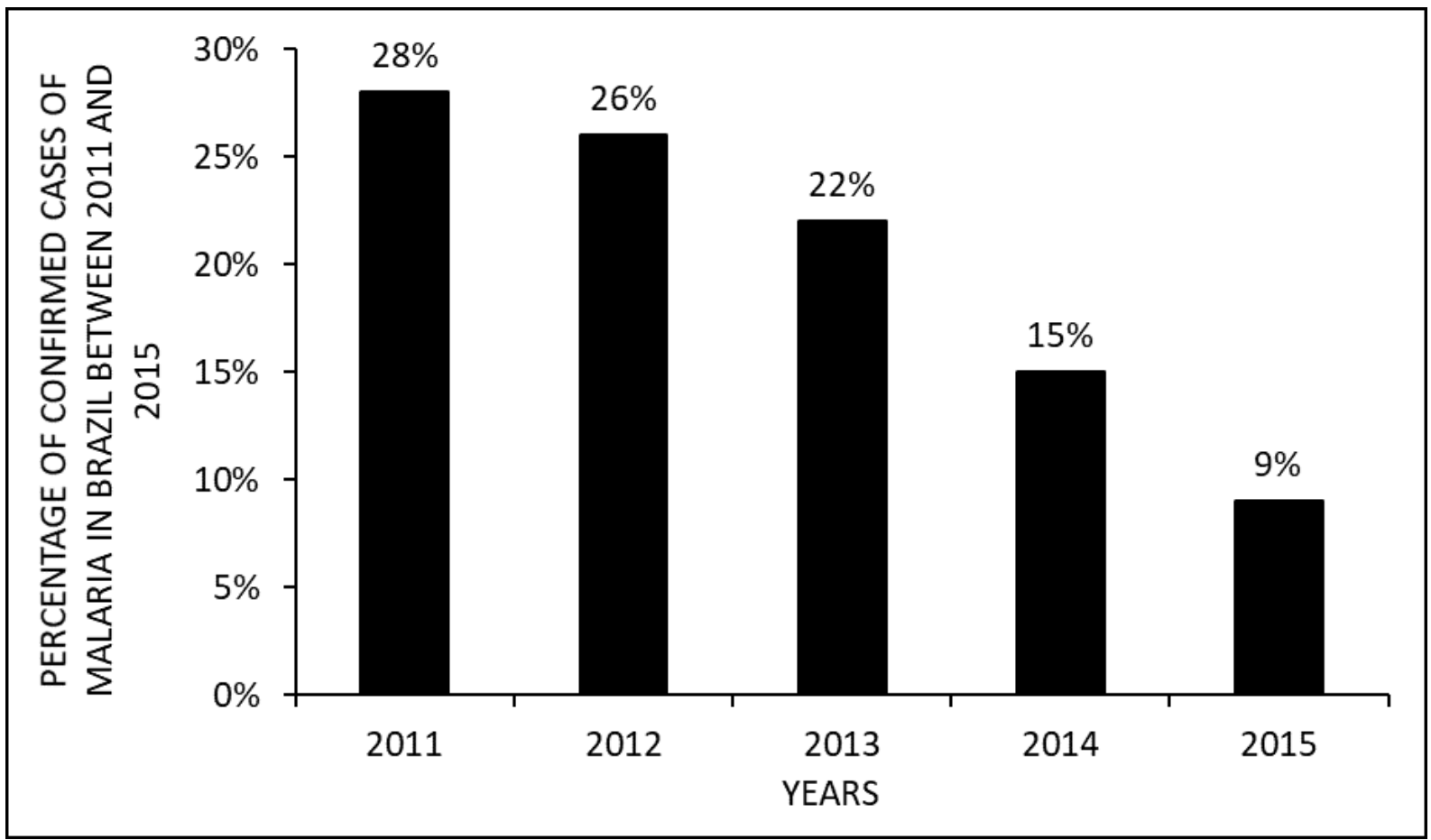

Figure 2 shows the percentage of confirmed cases of malaria in Brazil between the years 2011 to 2015 by age group (age range). The data show that the greatest number of cases of malaria occurred in people between the age group of 20 to 39 years, followed by the group between 49 and 59 years. 
Figure 2 Shows the percentage of confirmed cases of malaria in Brazil between the years 2011 to 2015, by age group (age range).

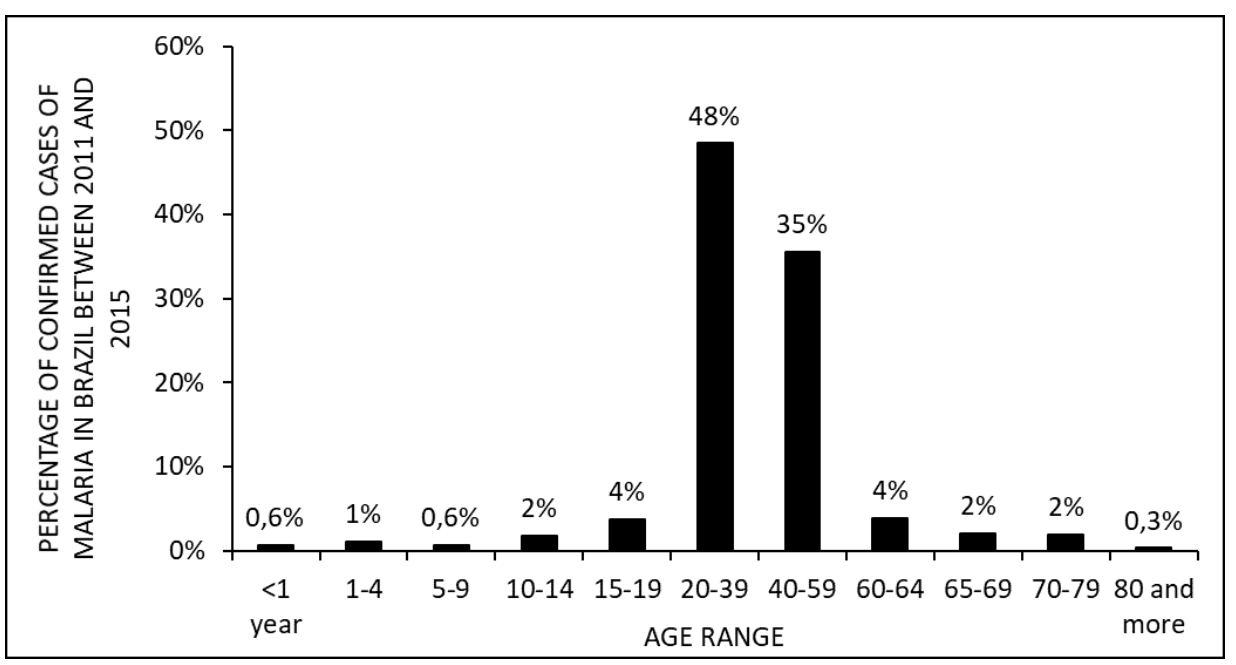

Figure 3 shows the percentage of confirmed cases of malaria in Brazil between the years 2011 to 2015 by gender. The data show that the greatest number of cases occurred with people of the male sex.

Figure 3 Shows the percentage of confirmed cases of malaria in Brazil between the years 2011 to 2015 by gender.

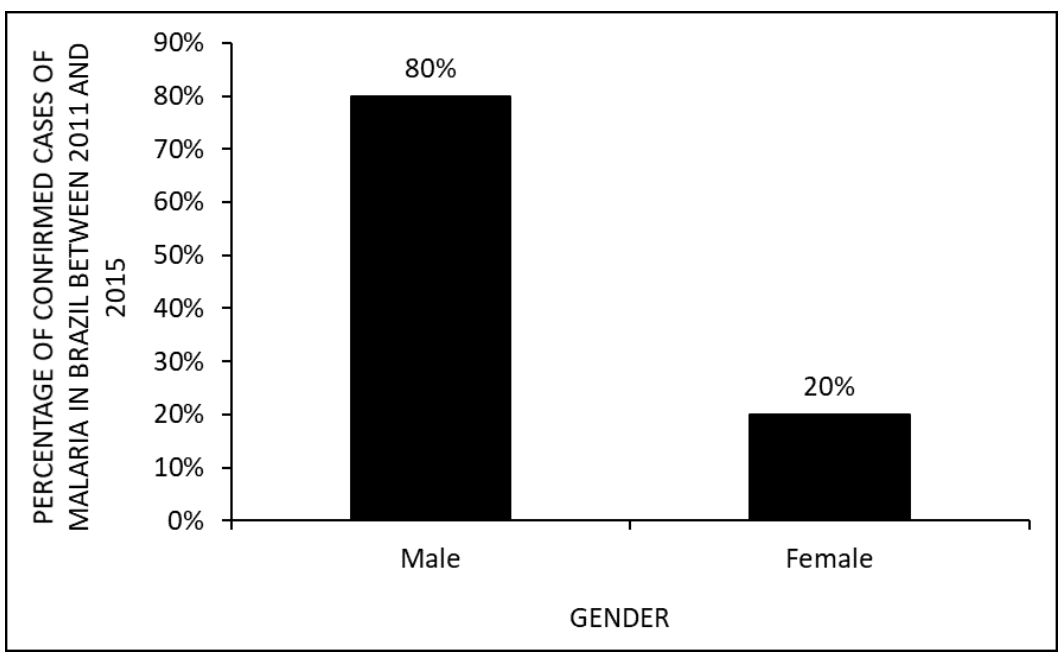

Figure 4 shows the percentage of confirmed cases of malaria in Brazil between the years 2011 to 2015 by race. The data show that the greatest number of cases occurred with white people followed by browns. 
Figure 4 Shows the percentage of confirmed cases of malaria in Brazil between the years 2011 to 2015 by race.

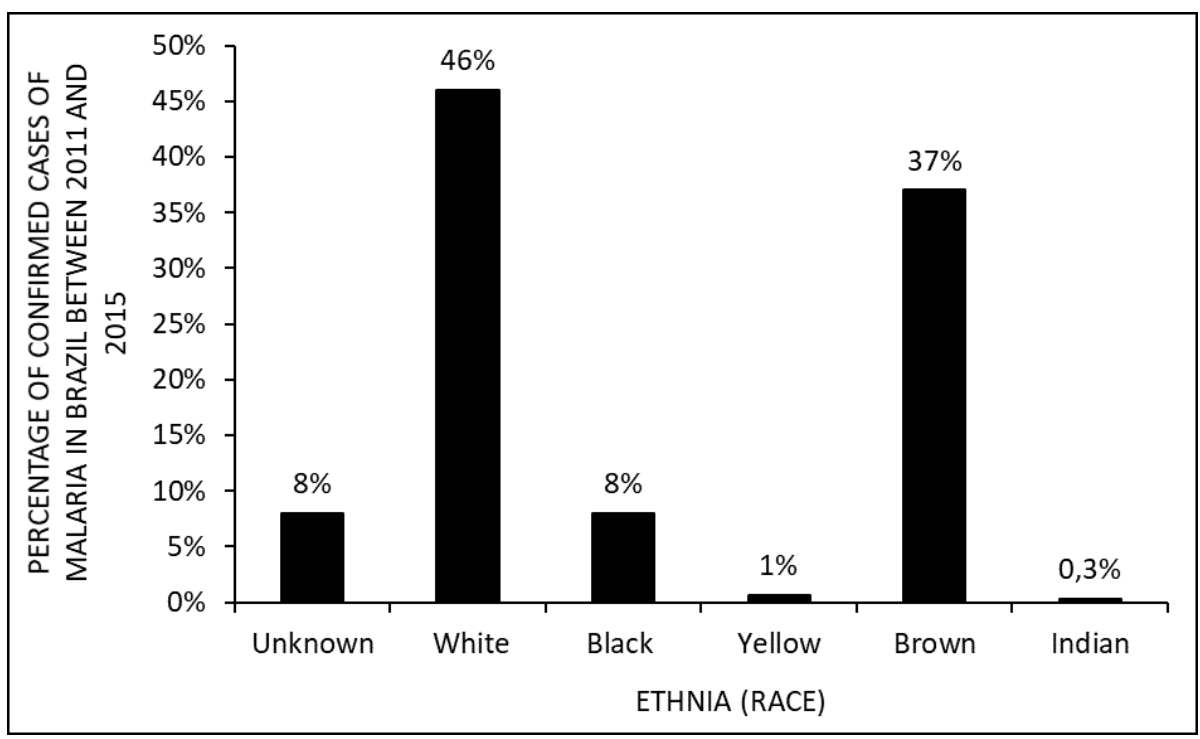

Figure 5 shows the percentage of confirmed cases of malaria in Brazil between the years 2011 to 2015 by schooling (scholarity). The data show that the highest number of cases per schooling (scholarity). is unknown. Where schooling is known, the highest numbers are with people from complete high school, followed by people with complete higher education.

Figure 5 Shows the percentage of confirmed cases of malaria in Brazil between the years 2011 to 2015 by scholarity.

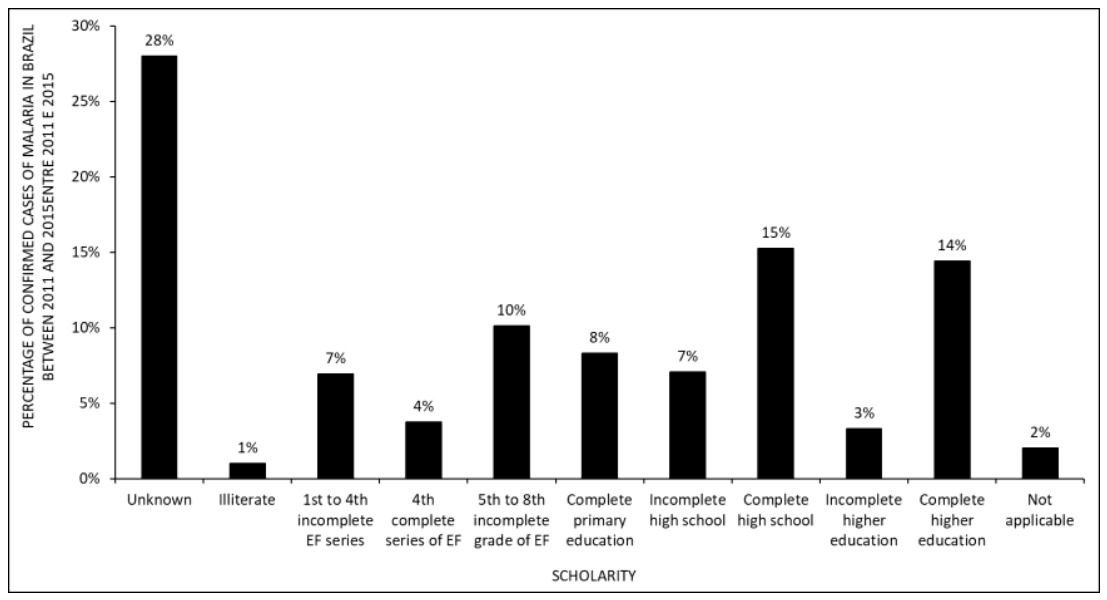


Figure 6 shows the percentage of confirmed cases of malaria in Brazil between the years 2011 to 2015 by area of residence. The data show that the greatest number of cases occurred in an urban area.

Figure 6 Shows the percentage of confirmed cases of malaria in Brazil between the years 2011 to 2015 by area of residence.

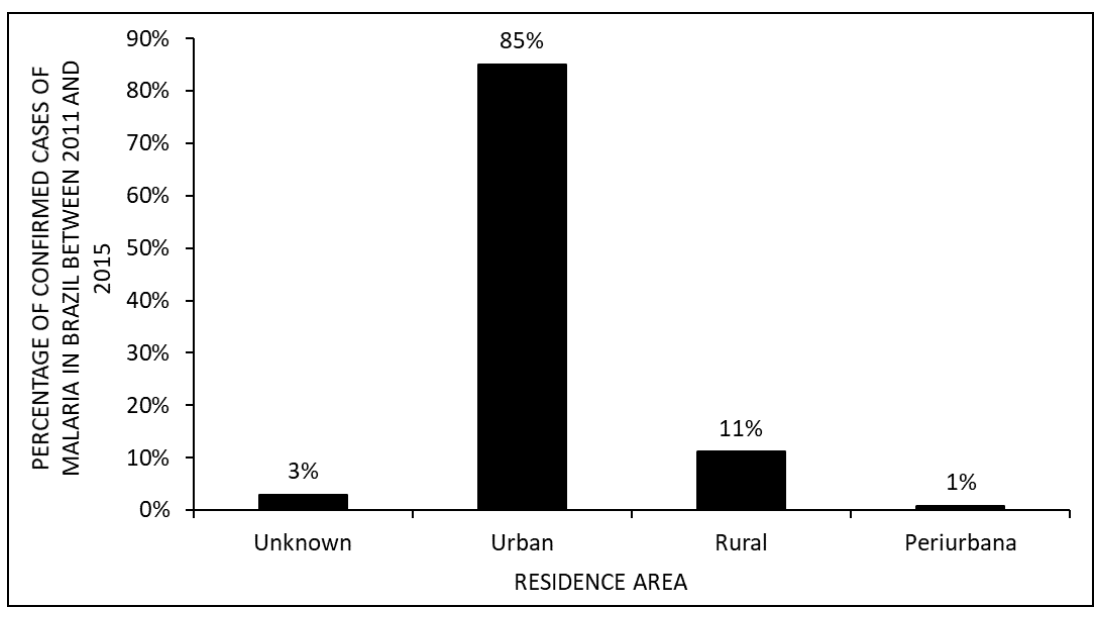

Figure 7 shows the percentage of confirmed cases of malaria in Brazil between the years 2011 to 2015 by regions of the country. The data show that the southeast region has the highest number of confirmed cases of malaria in the period.

Figure 7 Shows the percentage of confirmed cases of malaria in Brazil between the years 2011 to 2015 by regions of the country

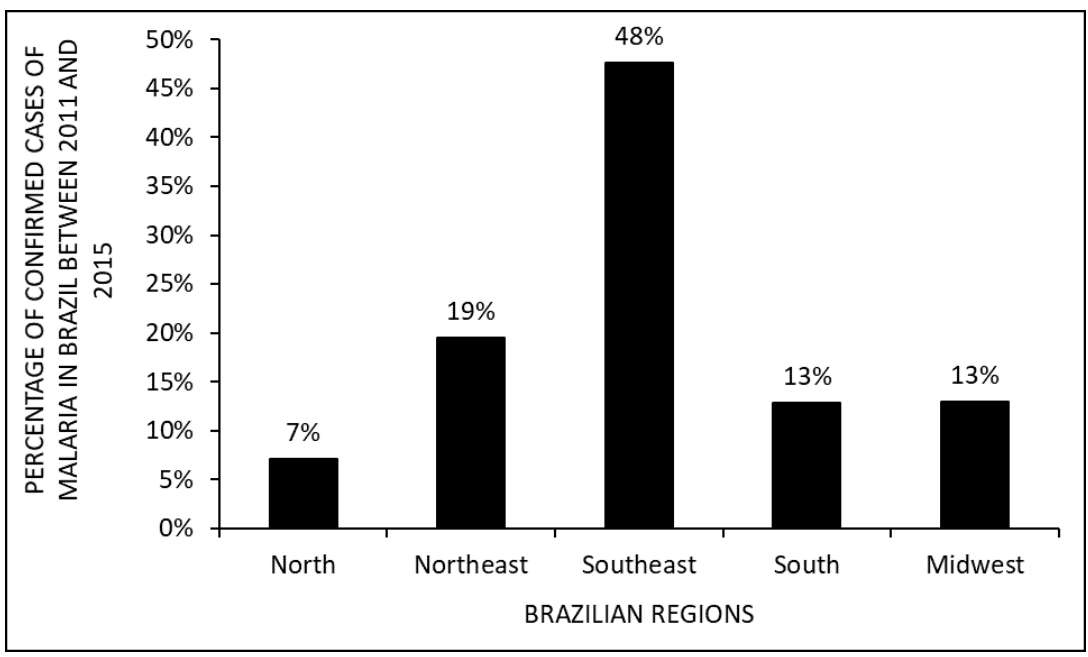


Figure 8 shows the percentage of confirmed cases of malaria in Brazil between the years 2011 to 2015 by states in the northern region of Brazil. The data show that the greatest number of cases occurred in the state of Rondônia

Figure 8 Shows the percentage of confirmed cases of malaria in Brazil between the years 2011 to 2015 by states in the northern region of Brazil.

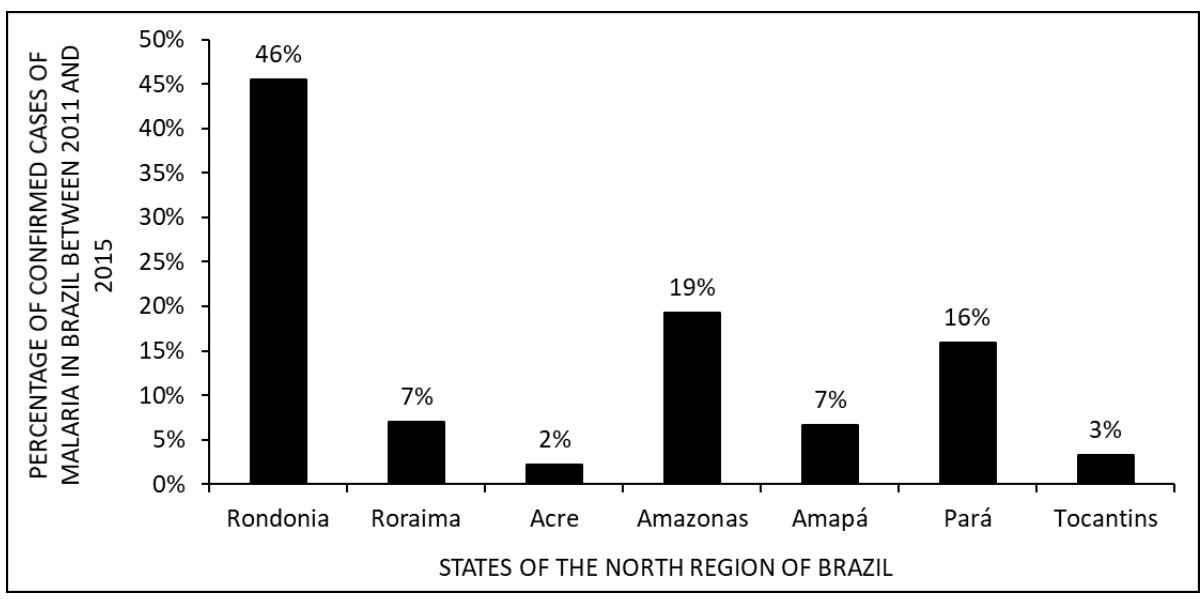

\section{DISCUSSION}

Data on the decline in the number of malaria cases between the years 2011 to 2015 (figure 1) are in accordance with the literature. The Federal Government, in analyzing the large number of malaria cases, carried out in 2015 the campaign "Eliminate Malaria for Good". This campaign possibly had a great influence on society, with the number of cases showing a reduction of $89 \%$ compared to previous years (BRASIL, 2017).

The data show that the highest number of cases of malaria occurred among people aged 20 to 39 years (figure 2). It seems that this age group is where most of the country's workers are found. Most people, men, work in areas with a higher risk of contamination and in places of vector proliferation (JUNIOR and LEVY, 2014; LUPPI et al., 2014).

Data on the number of malaria cases by gender show that the greatest number of cases occurred with people of the male sex (figure 3). Women seem to be more concerned with health and prevent disease much more. How much do men seek only 
when the disease is already installed (PINHEIRO et al., 2002). Men are also more likely to work in areas where mosquitoes proliferate (LUPPI et al., 2014).

Figure 4 shows that the largest number of cases occurred with white people followed by browns. In Brazil, ethnicity is self-declared and the majority of the population is recognized as being white and brown, respectively (PEREIRA et al., 2014).

The data show that the highest number of malaria cases in Brazil occurs with people in high school, followed by people with complete higher education (figure 5). According to IBGE (2017), there was an increase in the level of education of Brazilians between 2007 and 2014. Another probable reason is the installation of industries in places where there is a greater proliferation of mosquitoes. The demand of these companies is for professionals who have a good qualification, therefore, people who have completed high school and higher education (LUPPI et al., 2014).

Figure 6 shows that the largest number of cases occurred in an urban area. The mosquito seems to proliferate more easily in places where there have been man-made changes. The urban environment, because it is an extremely modified place, causes a greater number of cases due to the greater availability of breeding sites (BARATA, et al., 1993; VIEIRA et al., 2014).

The southeastern region of Brazil has the highest number of confirmed cases of malaria in the studied period (figure 7). This is one of the largest and most developed regions in the country, presenting a greater number of people at the expense of other regions. It is believed that for this reason this region has a greater number of cases and because it is also one of the regions of the country that has suffered the most changes by man, which seems to facilitate the proliferation of malaria (GUIMARÃES et al., 2015; BARATA, et al., 1993).

Of the states in the northern region of Brazil, Rondônia appears to have the highest number of cases of malaria (figure 8). It seems that the opening of highways and the increase of settlements facilitate the contact of the mosquito with man. The state of 
Rondônia has a large number of settlements and deforestation to accommodate progress (VIEIRA et al., 2014; BRASIL, 2015).

\section{CONCLUSION}

Campaigns had an influence on society and collaborated with the reduction of the number of communicable diseases like malaria.

Men work in areas with a higher risk of contamination and in places of vector proliferation, so they are more exposed to areas of mosquito proliferation and contagion.

In Brazil the majority of the population is recognized as being white and brown, respectively, so the numbers show these ethnicities as the most infected.

The mosquito seems to proliferate more easily in places where there have been manmade changes. The urban environment, as it is an extremely modified place, causes a greater number of cases due to the greater availability of breeding sites. It is believed that for this reason the southeastern region has a greater number of cases and because it is also one of the regions of the country that has suffered the most changes by man.

The opening of highways and the increase in settlements facilitate contact between mosquitoes and humans. The state of Rondônia has a large number of settlements and deforestation to accommodate progress.

\section{REFERENCES}

AREGAWI, S.; LI, L.; MIRAGLIA, C.M. Malaria rapid diagnostic test and Giemsa stained peripheral blood smear discrepancies in the diagnosis of Plasmodium ovale infection in New England. CLINICAL LABORATORY SCIENCE, v.30,2017.

BARATA, L. C. B.; ANDRIGUETTI, M. T. M. MATTOS, M. R. Surto de malária induzida entre usuários de drogas injetáveis. Rev. Saúde Pública, 27(1), 1993. 
BRASIL. Ministério da Saúde. Secretaria de Vigilância em Saúde. Departamento de Vigilância Epidemiológica. Guia prático de tratamento da malária no Brasil / Ministério da Saúde, Secretaria de Vigilância em Saúde, Departamento de Vigilância Epidemiológica. - Brasília : Ministério da Saúde, 2010. 36 p. : il. color. - (Série A. Normas e Manuais Técnicos).

BRASIL. Ministério da Saúde. Secretaria de Vigilância em Saúde. Departamento de Vigilância Epidemiológica. Boletim Epidemiológico/Ministério da Saúde, Secretaria de Vigilância em Saúde, Departamento de Vigilância Epidemiológica. - Brasília : Ministério da Saúde, V.46 N. 43, 2015

BRASIL, Brasil registra menor número de casos de malária nos últimos 35 anos. Disponível em: www.portalsaude.saude.gov.br. Acesso em: 19, setembro de 2017.

CAMARGO, E. P. Malária, Maleita, Paludismo. Ciência e Cultura, vol.55 no.1 São Paulo Jan./Mar 2003.

CAMARGO, E. P. A malária encenada no grande teatro social. Estudos Avançados, 9 (24), 1995.

CASTRO, M. C.; SINGER, B. H. Meio ambiente e saúde: metodologia para análise espacial da ocorrência de malária em projetos de assentamento. R. bras. Est. Pop., São Paulo, v. 24, n. 2, p. 247-262, jul./dez. 2007

GRILLO, M. L.; SILVA, L. T.; ARAÚJO, A. G. J; FARIAS, J. F. S.; RODRIGUEZ, D. A.; ROFATTO, F. A.; PRADO, M. L.; SILVA, L. G. B. A. Evolução do Número de Pessoas Infectadas por Malária no Brasil entre 2003 e 2015. I Encontro Acadêmico da Engenharia Ambiental da ELL-USP, 2017.

GUIMARÃES, R. M.; ANDRADE, S. S. C. A.; MACHADO, E. L.; BAHIA, C. A.; OLIVEIRA, M. M.; JACQUES, F. V. L. Diferenças regionais na transição da mortalidade por doenças cardiovasculares no Brasil, 1980 a 2012. Rev Panam Salud Publica. 2015;37(2):83-9. 
IBGE. Governo Federal. Educação. Disponivel em: <https://brasilemsintese.ibge.gov.br/educacao.html>. Acessado no dia 03 de outubro de 2017.

JOTTA, L. A. C. V.; CARNEIRO, M. H. S. Malária: As Imagens Utilizadas em Livros Didáticos de Biologia. Encontro Nacional de Pesquisa em Educação em Ciência. 8 nov/2009.

JÚNIOR, J. R. C. S.; LEVY, P. M. Impactos do Declínio do Bônus Demográfico Sobre a Oferta de Mão de Obra e o Crescimento Econômico no Período de 2014-2030. Carta de Conjuntura, 25/ dez. 2014.

LUPPI, O.; VIDIGAL, A. C.; LONGO, C.; COSTA, A. P.; SARAIVA, R. P.; RIBEIRO, C. T. D.; BRASIL, P. Estudo dos casos suspeitos de malária importada, um Centro de Referência na região extra-Amazônica. Centro de Informação Estratégica em Vigilância em Saúde, FIOCRUZ; Instituto de Pesquisa Clínica Evandro Chagas, FIOCRUZ, Brasil, 2014.

PINHEIRO, R. S.; VIACAVA, F.; TRAVASSOS, C.; BRITO, A. S. Gênero, morbidade, acesso e utilização de serviços de saúde no Brasil. Ciência \& Saúde Coletiva, 7(4):687-707, 2002.

SANTOS, J. A. G. Adesão ao tratamento da malária vivax em crianças. 2016. 74 f. Dissertação (Mestrado) - Universidade Federal do Pará, Instituto de Ciências da Saúde, Belém, 2016. Programa de Pós-Graduação em Ciências Farmacêuticas.

Submitted: April, 2020.

Approved: April, 2020. 